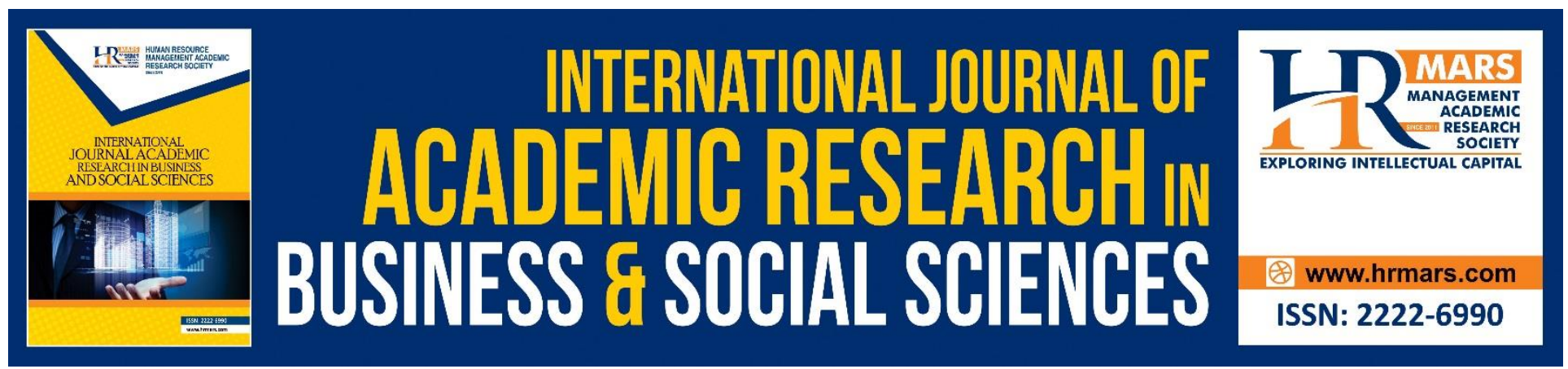

\title{
Method of Inquiry into the Islamic Economics among Contemporary Muslim Scholars: A Critical Literature Survey
}

M. Shabri Abd. Majid and Yahya

To Link this Article: http://dx.doi.org/10.6007/IJARBSS/v8-i9/4578

DOI: $\quad 10.6007 /$ IJARBSS/v8-i9/4578

Received: 12 July 2018, Revised: 19 August 2018, Accepted: 29 August 2018

Published Online: 28 September 2018

In-Text Citation: (Majid \& Yahya, 2018)

To Cite this Article: Majid, M. S. A., \& Yahya. (2018). Method of Inquiry into the Islamic Economics among Contemporary Muslim Scholars: A Critical Literature Survey. International Journal of Academic Research in Business and Social Sciences, 8(9), 105-117.

Copyright: (C) 2018 The Author(s)

Published by Human Resource Management Academic Research Society (www.hrmars.com)

This article is published under the Creative Commons Attribution (CC BY 4.0) license. Anyone may reproduce, distribute, translate and create derivative works of this article (for both commercial and non-commercial purposes), subject to full attribution to the original publication and authors. The full terms of this license may be seen at: http://creativecommons.org/licences/by/4.0/legalcode

Vol. 8, No. 9, September 2018, Pg. 105 - 117

Full Terms \& Conditions of access and use can be found at http://hrmars.com/index.php/pages/detail/publication-ethics 


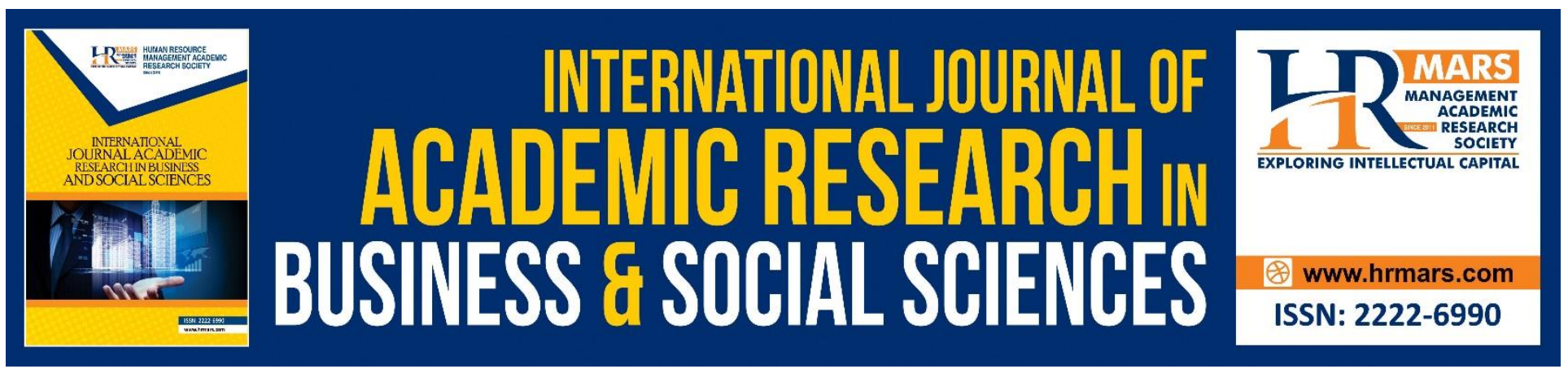

\title{
Method of Inquiry into the Islamic Economics among Contemporary Muslim Scholars: A Critical Literature Survey
}

\author{
M. Shabri Abd. Majid,$^{1^{*}}$ and Yahya ${ }^{2}$ \\ ${ }^{1}$ Department of Islamic Economics, Faculty of Economics \& Business, Syiah Kuala University, \\ Indonesia \\ ${ }^{2}$ Sekolah Tinggi IImu Ekonomi Sabang (STIES), Banda Aceh, Indonesia \\ *Corresponding Author: mshabri@unsyiah.ac.id
}

\begin{abstract}
Muslim economists adopt various approaches to analyze the nature of Islamic economics. The use of these different approaches leads to controversies among them. This study aims to discuss the controversies among the Muslim scholars with regards to the methods of inquiry into the economics. The study noticed that the controversies arise only in the matter of emphasis on certain economic aspects, but they unanimously agreed on the main sources, the Holy Qur'an and Hadith. Consequently, several contemporary Islamic economists have totally rejected the western thought, while some others have accepted with modification of some aspect of western thought. The former group is mainly consisting of jurists, while the latter group including the western trained economists. In responding to western economics, these groups totally disagreed on at least three basic assumptions of western economics as they are disharmony with the norms and values of Islam. These assumptions include: man is selfish by nature; material progress is a supreme goal; and every person has an inherent tendency to maximize his material welfare and also man possesses knowledge and ability to decide what is good and bad for himself/herself. However, there exist the differences in various strands or debate on the economic approaches for describing the nature of the Islamic economics.
\end{abstract}

Keywords: Philosophical foundation, Methodology, Islamic economics, Western economics, Contemporary Scholars.

\section{Introduction}

Every Muslim, including contemporary Islamic economist agrees that Qur'an and Hadith are the primary sources of Islamic knowledge. Islamic economics as a part of knowledge should rely on the Holy Qur'an and Hadith as its main references. In generating the Islamic economics, the approaches used either by the past Islamic economic scholars or the contemporary Islamic economists should not 
INTERNATIONAL JOURNAL OF ACADEMIC RESEARCH IN BUSINESS AND SOCIAL SCIENCES Vol. 8, No. 9, Sept. 2018, E-ISSN: 2222-6990 @ 2018 HRMARS

be isolated from these two main sources. Islamic economic approach or methodology as a subdiscipline within the Islamic economics plays a pivotal role in building and establishing the Islamic economic theories as a part of the Islamic economic system.

In describing the nature of the Islamic economics, the Muslim economists adopt various approaches used as framework to formulate Islamic economic theory and Islamic economic system. However, there have been no disagreements among the Islamic economists on the basic principles or foundation of Islamic economic system, particularly on the matters where there are a clear injunction in the Qur'an and Hadith. However, the existence of different views on the Islamic economic approaches among the Muslim economists, according to Khan (1989), is due to their diverse educational background. Khan (1989) categorizes the Islamic economic scholars into three groups, i.e., the ulama, modernists, and the western educated economists. In their writings on the Islamic economics, the ulama have ubiquitously adopted an orthodox approach, which traces all the teaching back to the sources. The modernists, on the other hand, have been mainly engaging in reinterpreting the primary sources and adjusting the ulama approaches to the contemporary situation. Meanwhile, the western educated economists have built the Islamic economic theories and models based on what the ulama have enunciated. ${ }^{1}$

Due to their differences in the educational backgrounds, some Muslim economists, for example, Mannan and Siddiqi, conclude that it is acceptable and nothing sinful in accepting the western economic approaches with some modification in the behavioural assumptions as long as it is in harmony with the Islamic values and norms. In accepting the conventional economic approaches, Naqvi emphasis the need to use more selective methods based on certain axioms derived from the Qur'an and Sunnah (Haneef, 1995).

In its early development, the contemporary Muslim economists have written the subjects of the Islamic economics by using various approaches. The proliferation of works in the Islamic economics showed that there have been very few scholars had tried to develop and elaborate a detailed Islamic economic approach that is consistent with the Islamic economic worldview. As far as the approaches used by contemporary Muslim economists in analyzing the nature of the Islamic economics are concerned, as we realized, there have been no study done in this area. Therefore to fill this gap, this paper is, however, mainly aimed at exploring the selected contemporary Muslim economists' approaches in describing the nature of Islamic economics. Among the contemporary Muslim economists who are discussed here are: Muhammad Nejatullah Siddiqi, Syed Nawab Haider Naqvi, Muhammmad Baqir al-Sadr, and Monzer Kahf and some other Muslim economic scholars. The paper also tries to compare their approaches in constructing the Islamic economic theory and Islamic economic system; be it a comparison among the Muslim economic scholars themselves and the comparison between the Islamic economics and its western counterpart.

The rest of this paper is constructed as follows; in next section, the paper reviews the Islamic economic approaches adopted by selected contemporary Islamic economists in describing the nature of the Islamic economics. In Section 3, their Islamic economic approaches are comparatively and critically

1 In their writings, most of them have presented their Islamic economic models and theories by using the mathematical applications and graphs. 
INTERNATIONAL JOURNAL OF ACADEMIC RESEARCH IN BUSINESS AND SOCIAL SCIENCES Vol. 8, No. 9, Sept. 2018, E-ISSN: 2222-6990 @ 2018 HRMARS

discussed. Before the conclusion is made in Section 5, a comparative analysis between the Islamic economic approaches and its conventional counterpart are critically analyzed in Section 4.

Islamic Economic Inquiry into the Economics: Selected Contemporary Muslim Economists Majorities of the Muslims scholars have emphasized the important role of usul al-figh as the main reference for deriving the Islamic economic approaches. In this respect, the approaches adopted by the contemporary Muslim economists should involve a deeper study on documentation of the primary sources and have to be based on the basic concepts such as tawhid, rubbubiya, khilafa, tazkiya and accountability (Arif, 1987). It is very difficult, not to say impossible, to present and identify the characteristics of knowledge and its behaviour unless by using a holistic approach via studying the integral part of the whole (Abu-Saud, 1993). In most of the contemporary works on Islamic economics, some of them have ignored the importance of these factors in their analysis. One quick proof of their ignorance on these factors can be found in their writings, where in small books they have a compilation of economic subject analysis. ${ }^{2}$ Although, there have been no distinctive approaches adopted by most of them, Naqvi (1981) in his book's "Ethics and Economics: An Islamic Synthesis" was able to provides a clear axiomatic approach. ${ }^{3}$ Now let us discuss critically the Islamic economic approaches adopted by selected prominent contemporary Muslim economists in describing the nature of Islamic economics. With the exception of Muhammad Baqir al-Sadr who is known as a jurist, all other contemporary Muslim economists discussed in this paper are the western trained economists, namely Muhammad Nejatullah Siddiqi, Syed Nawab Haider Naqvi and Monzer Kahf. ${ }^{4}$

\section{Muhammad Nejatullah Siddiqi}

The Islamic economic scholars extremely agreed that Qur'an and Hadith are the main sources of knowledge. According to Siddiqi (1988), the Holy Qur'an and Sunnah of the Prophet (pbuh) only laid down the basic principles relating to the economic matters. He is aware of the possibility of these principles being extended to varying times, circumstances, and places when the interpretation of these two main sources of the Islamic laws have no definitive meanings (qat'i). In responding to these changes, he stresses on the need of approaches to be dogmatic, accepting different approaches might be adopted by different institutions and people as long as they are in line with the principles of the Qur'an and Hadith. This is what he meant by the "universality" of the Islamic economics. He also argues that the Islamic tradition in economics has always been "free of formalism", concentrating on meaning and purpose with a "flexible" approach. To stimulate the expansion on the subject of Islamic economics, he asserts that Islamic economics must be "open" to contribution from other disciplines and both science and art must join hands to recognize the Islamic vision of a good life in economic affair. Thus he seems to imply that Islamic economics will be either a "multidisciplinary" or "interdisciplinary" social science. Since to build a new Islamic economic system is extremely difficult,

2 To mention a few, see Siddiqi (1978), Naqvi (1983), Kahf (1978) and etc.

${ }^{3}$ In the Preface of the book, the author has explained the approach adopted in his analysis (See Naqvi, 1981).

${ }^{4}$ Each of them has written extensively on the economic issues and at least one major work on the Islamic economics. However, the name's order does not indicate their numbers of works/writings are larger than the others (the number of works Siddiqi are not necessarily greater than the other contemporary Muslim economists, e.g. Kahf). The ideas of all these contemporary scholars of Islamic economists' views are largely taken from Haneef (1995). 
not to say impossible, it is nothing sinful to accept certain aspects of the western economic analysis as long as it is in harmony with the Islamic jurisprudence. It is important to notice that his "accommodative approach" is not meant to accept everything from conventional economics as it looks good at its surfaces without scrutinizing the real substance and essences of the western economic concepts whether it is Shari'ah compliance or not. After screening process on the explicit and implicit essences of the conventional theories, then only the selected analyses of the conventional economics are acceptable and therefore can be adopted by Muslim economists.

In general, the main characteristics of Siddiqi's approach are at least two folds. First, he accepts the neoclassical theory and its tools of analysis. When dealing with "existing reality", though adjustment in the assumptions, behavioural norms and goals of conventional economics are made to portray the Islamic perspective; he makes no apology for accepting the neoclassical framework and analysis. The most important thing is that, he says, to modify the analysis with "good reason" by indicating the shortcomings of western economic analysis. Once it is done, new tools can be-and have been designed and a new instrument-forwarded to help the Islamic economy to attain its policy ends. Second, he sees that the Islamic economist is an "Islamizing agent', which means that it is not acceptable to totally generating the Islamic economic theory based on observations (empiricism) (Haneef, 1995). Because the truthfulness of the observations is very limited in its application and it only presents the phenomenon of nature and economic experiences. The Divine injunction should be taken into consideration in forming the Islamic economic theory. The role of values in economics should also be taken into account in the approaches of Islamic economics. It is also necessary to have a fresh look at these values in modifying and implementing a new theory in the Islamic economics (Siddiqi, 1981).

In a nutshell, as a western trained economist, Siddiqi approach is basically neoclassical, reflecting their conventional economics training. In most of his writings, however, Siddiqi a Keynesian par-excellence, sees Islamic economic as emanating from the worldview, dominated by revelation and having a flexible methodology and seem to be merging figh with the western neoclassical or the Keynesian approach.

\section{Syed Nawab Haider Naqvi}

Like others scholars, Naqvi (1981) absolutely has no doubt on the comprehensive guideline and rules enshrined by the Holy Qur'an and Hadith on man's behaviour, which he termed as the first principles or value references. His well-known "axiomatic approach" - Islamic ethical axiom-is derived based on these main references, the Qur'an and Hadith, which represent a coherently, internally, economically and socially viable Islamic economic system. This axiomatic approach contains a set of four axioms, namely, "unity", "equilibrium", "free will", and "responsibility" (Naqvi, 1981, 1994 and Haneef, 1995). As a Muslim there should be no question to accept these axioms. His theory is actually rooted from his perception on the Islamic economic is as a sub-set of its cosmic ethical vision. Therefore, to make valid statements about the basic economic motivation and processes in the Muslim society, the ethical proposition must be used as the main reference points (Naqvi, 1994). Thus, the ethical values and the acceptance of religion as the sources of ethic make Islamic economics distinct from the capitalism and socialism. 
INTERNATIONAL JOURNAL OF ACADEMIC RESEARCH IN BUSINESS AND SOCIAL SCIENCES Vol. 8, No. 9, Sept. 2018, E-ISSN: 2222-6990 @ 2018 HRMARS

His axiomatic approach, which was supported by Sadr and also agreed by Siddiqi, is able to selectively assimilate elements in the modern economics, which are not contradictory to the Islamic economic philosophy. This implies that the axiomatic approach helps us to assimilate our models of Islamic economics with the modern economics components which are compatible with the Islamic ethical axioms. By the same token, this approach does not allow us to indiscriminate borrowing the ideas from the non-Islamic economic systems. Though, as a western trained economist, Naqvi vehemently disagrees, in his approach, with any attempts to purify capitalism or to make cosmetic changes to the neoclassical framework by indiscriminating syncretism and to call it the Islamic economics. According to him, it is impossible to Islamize the existing economic system by only adding the Islamic elements or using the Islamic terminology without ensuring the value premises, which distinguish the Islamicity of the system are retained (Haneef, 1995). Also the elements contains in the modern economics that are non-Shari'ah compliance and against the Islamic spirits like usury (riba), uncertainty (gharar), gambling (maisir) and etc should not be adopted into the Islamic economic system.

Basically, Naqvi's approach - which also claimed as deductive approach ${ }^{5}$ - has indirectly answered the questions raised by Syeik Idris (1987) in the beginning of his article:

"How do we make something Islamic, including Islamic economic, of course, which is already so? Or is it your intention merely to give each form of knowledge an Islamic flavour by injection an "ayat" here, imposing a "Hadith" there, making an opening with "bismillahi-rrahmani-rrahim" and a closing with "alhamdu lillahi rabbi-l'alamin"?

\section{Muhammad Baqir al-Sadr}

Sadr (1983) has defined the Islamic economics as the way Islam prefers to follow in the pursuit of its economics life and in the solution to its practical problems that is in line with its concept of justice. ${ }^{6}$ Islamic economics is a prescriptive doctrine and not an analytical science dealing with the positive or technical aspects of economics. Unlike Siddiqi, Naqvi, Kahf and Khan who are the western trained economists, Sadr is known as a jurist. In his lqtisaduna, he demonstrates his independent approach, but qualified intellectual assertion (Haneef, 1995). Although he agreed on the independence of the Islamic economics from its conventional counterpart but he did not consider the Islamic economics to be equivalent to fiqh mu'amalah. To him, the Islamic doctrine is the foundation upon which laws relating to economics are shaped. These laws are determined in the spirit of and with reference to the theories and conception, which the doctrine represents.

Furthermore, he believes that there is a completely formed and finished system of economics, although it may not be clearly spelt out by the Qur'an and Sunnah, especially the saying of the Shi'i Imam. In his discovery process, all economics' laws and injunctions together with numerous concept related to economics and society-vicegerency (khilafah), justice ('adl), property (amwal), worship (ubudiyyah) and so on-should be studied together to discover the economic doctrine. The need of qualified ljtihad (intellectual exercise) to meet contemporary problems and the fact that we cannot blindly follow one jurist's opinion as well as the need to free analysis from the western theoretical framework and worldview are of his important view on the Islamic economic approach used to analyze the nature of Islamic economics (Haneef, 1995).

5 This "deductive method" adopted by him as he has claimed by himself (Naqvi, 1994, p. 155).

${ }^{6}$ This concept may be based on well-known Hadith, "Justice is the basic ruling of authority". 
INTERNATIONAL JOURNAL OF ACADEMIC RESEARCH IN BUSINESS AND SOCIAL SCIENCES Vol. 8, No. 9, Sept. 2018, E-ISSN: 2222-6990 @ 2018 HRMARS

Sadr further argues that the need for ljtihad is necessary to fill the gap between the permanent principles and flexible laws to determine the limits of inquiry and to organize theoretically the final concept into a coherent whole. In arguing and explaining the economic phenomenon, he allows the possibility of varying opinions on economic matters as legally sound and derived from the Qur'an and Sunnah. The overall objectives are of permanent value and there are references to temporal situations. However, one of the most important elements in building blocks towards developing a viable approach and framework for economics is the realization that an Islamic solution can vary in surface or even in form, but the basic principles remain the same (Mahdi, 1987).

Methodologically, Esposito (1995) disagrees with Sadr because in his prominent work of Iqtisaduna, he has acknowledged that there is no "scientific discipline" in Islam that can be identified as economics, thereby the main elements in the approach to an Islamic economics must be derived from what he called "the legal superstructure". He simply believes that the resultant process, which leads to the well known operation of ljtihad as it is understood in a wider definition as "an intellectual endeavour into the law and jurisprudence of classical Islam and is consequently acknowledged as an exercise which is prone to human error". According to Sadr, the "Islamic economic is not science" and will only stand as an original and serious discipline after a long process of legal discovery. After doing a thorough research, then one can speak of an original Islamic discipline of economics, in which the moral imperative derived from the law is clear but in which also there is a difficult and patient scholarly investigation into the riches of the classical figh tradition.

From a substantive point of view, in his lqtisaduna, Sadr has criticized the Marxist socialism and Western capitalism before offering his alternative system. He developed a long-winded and informed argument demonstrating the fallacies of Marxist periodization of history; its overemphasis on the class struggle, and its unrealistic prescription against the basic and natural instinct of economic selfinterest in mankind.

\section{Monzer Kahf}

In his analysis on the nature of Islamic economics, Kahf (1978), on the other hand, perceives the Islamic economics as a branch of the science of economics but based on the Islamic Paradigm. ${ }^{7}$ Although the Islamic philosophy and principles differ from the western economics, he opines that the approach and logic used in the Islamic economics might be the same with the conventional ones. But, the Muslim scholars should admit a universal norm regarding man's economic behaviour based on the Qur'an and Hadith. To him, the approach and methodology used in the Islamic economics would be similar to its conventional counterpart such as in terms of using mathematical logic and empiricism (Haneef, 1995). He simply claims that the tools of economic analysis are not exclusive and restrictive for one system, but it is for everyone. However, he realizes and agrees that the Islamic approach will

\footnotetext{
${ }^{7}$ See Arif (1987). According to him, paradigm can be defined as "a concept of reality that informs all thoughts within its frame of reference until unavoidable facts of reality conflict with it and cause its adherents to reject this first paradigm for another one". Meanwhile, Thomas Kuhn's defined paradigm "as what the members of scientific community and alone share". Conversely, it is their possession of a common paradigm that constitutes a scientific community of a group of otherwise disparate men.
} 
entail some shifting of analysis and sometimes a different way of formulating certain economic questions, but these modifications will not justify claims of a unique and distinct approach.

Like the conventional economic systems, the Islamic economic system also should be based on an ideology that provides the economic system with its basis and objectives on one hand and with its axioms and principles on the other. In other words, a system for Islamic economics should be formulated on the basis of the Islamic doctrine of life. In designing the Islamic economic system, he says that the axioms and principles should be stipulated and the process of its functioning should be clarified in order to show its purity and applicability. The other important point with regards to the approach in the Islamic economics is the distinction between fiqh mu'amalah (business law) and the Islamic economics should be clearly spelt. The lack of such distinction may create misconception in understanding the Islamic economics. Actually, figh mu'amalat draws up the legal framework for the Islamic economics, while the Islamic economics itself is the study on the process and outcome of human activity relating to the economic activities such as consumption, production, distribution and etc.

In analyzing the nature of the Islamic economics, the study of history should be taken seriously into consideration since the history is the laboratory of humanity (Kahf, 1978). The historical approach should eventually equip the guidelines and references as a mirror to reflect new theories with some possible adjustments and modifications. Based on historical phenomenon, he realized that the present literature on economics has utilized two alternate methods. These methods have also been applied by him, namely the deductive and retrospect thinking methods. The former method is commonly adopted by al-fuqaha and applies it in the modern Islamic economics in order to deduce the principle of the Islamic system and its legal framework based on the Holy Qur'an and Sunnah. The latter method is generally employed by the contemporary Muslim scholars in order to find solutions to economic problems of the Muslims by reverting to the Islamic jurisprudence and then tests them in the light of the Divine revelation.

\section{Some Other Contemporary Muslim Economists}

Muhammad Abdul Mannan (1980), generally, describes the Islamic economic system as one of that is broadly capitalistic, restricted by socialistic institutions and ideas, one that he term as "Islamic socialism" or "democracy". In his writings, as a western trained economist, Mannan adopts an "eclectic" method that takes the entire good features from capitalist and socialist system by throwing away all bad aspects from them. However, he admits that in Islam, a Muslim is only confined to the Islamic man, not economic man, and to the permitted boundaries of economic activities in Islam (Haneef, 1995).

Sayyid Mahmud Taleghani, on the other hand, has considered litihad as a very important element in deriving the theory of Islamic economics and legalizing the activities in Islamic economics. Consequently, he places a great responsible role of ulama and mujtahidun in overcoming the contemporary problems in the Islamic economics. All in all, as a jurist, his views are most likely similar to those of Sadr. 
INTERNATIONAL JOURNAL OF ACADEMIC RESEARCH IN BUSINESS AND SOCIAL SCIENCES

Vol. 8, No. 9, Sept. 2018, E-ISSN: 2222-6990 @ 2018 HRMARS

\section{Islamic Method of Inquiry into the Economics among the Contemporary Muslim Scholars: A Comparison}

Based on the above discussion, all the contemporary scholars of Islamic economists agree to base their Islamic economic approach on the Qur'an and Hadith as well as tawhidic view as their parameter for generating the Islamic economic theory and the Islamic economic system. It is not only Sadr and Taleghani who agree that contemporary economic problems required new solutions through ljtihad, the rest of them also consider ljtihad as the best way to produce a new idea or theory. In deriving the Islamic economic theory, they argue that as either multidisciplinary or interdisciplinary, the Islamic economics should recognize the extended horizon line of akhira (Hereafter) and pursuance of falah (the happiness in this world and Hereafter) as the fundamental building block for decision-making in the Islamic economics.

Siddiqi and Mannan's view on the Islamic man indicate the possibility of including non-Muslim who is willing to accept the Qur'an and Sunnah and the Islamic worldview as main guide for their economic activities. Sadr's and Taleghani's juristic approach, on the other hand, demarcates a clear picture between Muslim and non-Muslim. Naqvi, who calls for a totally restricted framework based on his well-known ethical axioms derived from the Qur'an and Hadith, is against any attempt to purify capitalism or to equate Islam with socialism or the welfare state. He consistently argues that the Islamic economists should not be afraid of being branded if they honestly and sincerely derive certain proposition and principles from the Qur'an and Hadith. In short, the Islamic worldview is shaped based on the Qur'an and Hadith for the purpose of achieving Maqashid al-Shari'ah (Ahmad and Hanapi, (2018).

Moreover, Kahf does not agree with the constant attempts by some Muslim economists to exaggerate differences between the western and Islamic economics. He reminds the Islamic economists of the importance of categorization, epistemology and especially methodology when trying to develop the Islamic economic discipline. Furthermore, he adds that a system of Islamic economic should be formulated on the basis of the Islamic doctrine of life. The axioms and principles of a system should be stipulated and the process of its functioning should be clarified in order to show its purity and applicability (Kahf, 1989). His view, however, can be put somewhere in between Siddiqi and Naqvi's perceptions.

Finally, as a jurist, Sadr and Taleghani seem to limit their analysis only to the doctrine of economics. They have spent much of their efforts only for justifying and differentiating the Islamic economic system from capitalist and socialist systems. Sard, particularly looks at religion as the main guide to arrest unbecoming behaviour in the economic activity is very pronounced. To him, his Prophetic approach offers a cure for the mind and heart precedes cure for socio-economic problem. It is his recognition of the role of religion in the economic activity that distinguishes the Islamic economic system from other man-made systems (Haneef, 1995). Additionally, in order to build the ideal Islamic approach, Abu Sulayman (1993) offers five most important basic concepts, i.e., the purposeful nature of creation and existence; the objectivity of truth and relativity of circumstances; freedom of decision and freewill; the comprehensiveness of tawakkal; and the causality of deeds.

Conventional vs. Islamic Method of Inquiry into the Economics: A Comparative Analysis 
INTERNATIONAL JOURNAL OF ACADEMIC RESEARCH IN BUSINESS AND SOCIAL SCIENCES Vol. 8, No. 9, Sept. 2018, E-ISSN: 2222-6990 @ 2018 HRMARS

Although all religions deal with economic matters but they differ in their stands concerning economic activities. Certain religions other than Islam looks at the economic activities of man as a necessity of life, which ought to be undertaken only to an extent that provides him with mere sustenance, considering any further economic exercise beyond the limit as disorientation of human resources some sort of evil. Accordingly, such religion considers those who are less involved in the economic activities to be closer to the God. Islam on the contrary, considers the economic activities of man as an aspect of the fulfilment of his responsibility on this earth as vicegerent (khalifah). The more man is involving in the economic activities the better he could be, provided his life is kept balance (Arif, 1985).

Furthermore, the Islamic economists have challenged many of the assumptions of neoclassical economics (Siddiqi, 2001). There exists the differences in various strands or debate on approaches to economics, but there is also abroad agreement of western economics on three basic assumption points, i.e., (i) man is selfish by nature and behave rationally; (ii) material progress is a supreme goal and every person has an inherent tendency to maximize his material welfare; and (iii) man also possesses knowledge and ability to decide what is good and bad for himself (Khan, 1989). The Islamic view is quite different on this point. First, it is not true that man is selfish. There have been overwhelming evidences that all civilized societies have been motivated by altruism motives, ${ }^{8}$ rather than selfishness. Second, the material progress is not a supreme objective in the Islamic society. ${ }^{9}$ However, desirable it is, it is subservient to the falah in the Hereafter. This does not imply that Islam prohibits its ummah from being rich. But material prosperity, Islamically, is desirable so far it helps one to perform his duties towards God, society, family, and one's own self. ${ }^{10}$ Third, Islam perceives man as incapable of knowing what is the best for him ${ }^{11}$ and the only God who owns a perfect knowledge. Therefore, if the economic basic assumptions are different, automatically the Islamic economic approaches to analyze the nature of economics would also be different.

Since its inception, the Islamic economic approach has followed a very different path from that of western methodology. For example, in using the tools of neoclassical economics, the Islamic economists adopt a value-laden worldview that opposed the free-value of neoclassical economists. The differences in the Islamic approaches are more of emphasis than of theory. Moreover, both the deduction and induction are acceptable methods of analysis in the Islamic economics as far as it complies with the Islamic Law. Unlike the western empiricism-sense experience does not provide the absolute proof for truth, the Islamic economic approach, in fact, must be distinguished from truth, while proofs from sense experience cannot escape the criteria and proof from revelation.

As mentioned earlier, like other knowledge, the Islamic economics also considers Divine revelation as the main principles and sources of knowledge. Western economists, on the other hand, define its authority in such a manner that it is assigned a very marginal and subordinate role among the source of knowledge. In this respect, John Locke argues that knowledge acquired by human reasoning is more

\footnotetext{
${ }^{8}$ Many Qur'anic verses show about this, especially the terminology which are relate to sadaqah, zakat, silaturrahmi, ta'awun (cooperation) and brotherhood, etc.

${ }^{9}$ See Qur'an (6: 32; 14: 3; 16: 107; 75: 20-21; and 100: 8).

${ }^{10}$ See the well-known Hadith narrated by Ibn al-Hakim: "(lawful) wealth for a virtues man is an excellent thing".

${ }^{11}$ See Qur'an (4: 11).
} 
INTERNATIONAL JOURNAL OF ACADEMIC RESEARCH IN BUSINESS AND SOCIAL SCIENCES

Vol. 8, No. 9, Sept. 2018, E-ISSN: 2222-6990 @ 2018 HRMARS

certain than knowledge received trough revelation. He gives revelation the upper hand over reason in two instances: first, in the question belonging to the realm of faith. This realm being inaccessible to human reasoning and is governed by revelation. Second, revelation should supersede reason in the realm of probable knowledge, which does not rise, to the level of certainty (Safi, 1996).

The Western paradigm based on the materialism gives limited worldview and a specific theory of knowledge (Arif, 1987). In the western paradigm of materialism, there are no divine revelations and prophets are merely great man, wise men or heroes. Knowledge and investigation in the western paradigm are limited only to the world that is knowable through the sense and thus only statements about the sensible will make sense. This principle of the western paradigm is known as the logical positive theory of meaning. However, the basic position of the Islamic theory of knowledge is found on the principle that "Islamic epistemology begins with the premise that originally all knowledge is Allah's knowledge". If we relate to the Popperian falsification and western logical positivism approaches, of course, the revelation in Islam cannot be falsified forever by mankind. Muslims must believe absolutely to the Divine injunction without having any bargaining power to refuse it.

Based on these differences, it is clear that the economic approaches developed by the western economic scholars cannot be used by the Muslim scholars for studying human phenomena for, at least, two reasons: (i) the metaphysical foundation of western scholarship has never been explicitly discussed but always implicitly presupposed; and (ii) it does not accord with the ontology of revelation (Safi, 1996). Many western approaches are simply designed to deduce conclusions from models developed by contemplating western experiences, while the Muslim economic approach does not necessarily to achieve these purposes. In practice, the adoption of the western principles into the economy has caused Indonesia to suffer from episodes of economic crises. If Indonesia would like to run away from the crisis, the Islamic economic principles should be implemented in the biggest Muslim populous country in the world (Ag and Baru, 2017).

\section{Concluding Remarks}

Since the Islamic society is fundamentally different from the western secular societies in the values and norms, thus the western economic methods are not suitable to apply in the Islamic economics. In solving these matters, the contemporary Islamic economic scholars have been trying to build their own approaches derived from the Holy Qur'an and Hadith. In his flexible approach, Siddiqi stresses the need to be dogmatic and to realize that there can be different institutions and solutions adapted to different people. It is only natural and acceptable as long as Islam accepts them. Naqvi's axiomatic approach suggests that the Islamic economists can selectively assimilate elements in modern economics that are in harmony with the Islamic economic values and norms. However, it is not possible to Islamize existing economic system by only adding the Islamic elements or using the Islamic terminology "by injection an ayat here, imposing a hadith there, making an opening with bismillahirrahmani-rrahim and a closing with alhamdu lillahi rabbi-l'alamin" as proclaimed by Syeik Idris (1987). Other scholars, Sadr, in his Iqtisaduna, and Taleghani demonstrate independent approaches, but qualified intellectual assertion. As the jurists, they emphasize that the qualified ljtihad is needed in order to meet the contemporary problems and the fact that Muslim cannot blindly follow one jurist's opinion as well as the need to free analysis from western thought framework and worldview. Mannan's eclectic approach, on the other hand, receives all the good features from capitalist and 
INTERNATIONAL JOURNAL OF ACADEMIC RESEARCH IN BUSINESS AND SOCIAL SCIENCES

Vol. 8, No. 9, Sept. 2018, E-ISSN: 2222-6990 @ 2018 HRMARS

socialist system. Finally, Kahf says, the Islamic economics would be similar to its conventional counterpart as far as the approached and methodological issues are concerned.

In a nutshell, there has been a broad agreement on at least three basic assumptions - man is selfish, person's tendency to maximize profit, men posses the complete knowledge is extremely different to the Islamic economics. In the Islamic economics, it is not true that man is selfish; there have been overwhelming evidences that all civilized socialites man has been motivated by altruism motives; and the material progress is not a supreme objective in Islamic society. The material or wealth is only subservient to the falah in the Hereafter. In the western economics, on the other hand, Divine revelation is placed in a very marginal and subordinate role among the sources of knowledge as it is argued by John Locke that knowledge acquired by human reasoning is more certain than knowledge received trough revelation.

Based on these findings, future researches studying approaches to Islamic economics should be based on an Islamic worldview, derived from the Holy Qur'an and Hadith. Controversies are allowed only in the matter of emphasis on certain economic aspects, but the scholars should unanimously agree on the main sources of references, the Holy Qur'an and Hadith.

\section{References}

Abu Sulayman, A. H. (1993). Crisis in the Muslim Mind, translated by Yusuf Talal De Lorenzo, USA: International Graphics Point Services.

Abu-Saud, M. (1993). The methodology of the Islamic behavioral sciences, The American Journal of Islamic Social Sciences, 14(2), 23-34.

Ag, I. M., \& Baru, R. (2017). The principles of Islamic economics and their Implementation in Indonesia. International Journal of Academic Research in Business and Social Sciences, 7(4), 331-344.

Ahmad, N., \& Hanapi, M. S. (2018). Maqasid al-syariah thought in mainstream Islamic economics: a review. International Journal of Academic Research in Business and Social Sciences, 8(4), 626636.

Anwar, M. (1991). "Islamic Economic Methodology", in Faridi, F. R (ed), Essay in Islamic economic Analysis, New Delhi: Genuine Pub and Media PVT. Ltd.

Arif, M. (1985). Toward the shari'ah paradigm of Islamic economics: the beginning a scientific

revolution, The American Journal of Islamic Social Sciences, 2(1), 79-98.

Arif, M. (1987). The Islamization of knowledge and some methodological issues in paradigm building: the general case of social science with a specific focus on economics, The American Journal of Islamic Social Sciences, 4(1), 51-63.

Esposito, J. L. (1995). The Oxford Encyclopaedia of the Modern Islamic World, Vol. 3, and New York: Oxford University press.

Haneef, M. A. (1995). Contemporary Islamic Economic Thought: A Selected Comparison Analysis, Kuala Lumpur: Ikraq.

Haneef, M. A. (1997). Islam: the Islamic worldview, and Islamic economics, IIUM Journal of Economics and Management, 5(1), 39-65.

Kahf, M. (1978). The Islamic Economy: Analytical Study of the Functioning of the Islamic Economic System, Plainfield: Muslim Students Association of the USA and Canada. 
INTERNATIONAL JOURNAL OF ACADEMIC RESEARCH IN BUSINESS AND SOCIAL SCIENCES

Vol. 8, No. 9, Sept. 2018, E-ISSN: 2222-6990 @ 2018 HRMARS

Kahf, M. (1989). "Islamic Economics and its Methodology", in Syed Ghazali and Omar (ed) Reading in the Concept and Methodology of Islamic Economics, Malaysia: Pelanduk Publication.

Khan, M. A. (1989). "Islamic Economics: The State of Arts", in Aidit Ghazali and Syed Omar (ed) Reading in the Concept and Methodology of Islamic Economics, Malaysia: Pelanduk Publication.

Khan, M. A. (1989). "Methodology of Islamic Economics", in Syed Ghazali and Syed Omar (ed) Readings in Concept and Methodology of Islamic Economics, Malaysia: Pelanduk Publication.

Mahdi, S. I. (1990). Islamic approach to model building in economics and other social sciences: a methodological framework. Journal of Objective Studies, 2(1), 83-94.

Naqvi, S. N. H. (1980). An Islamic approach to economic development. The Symposium on Islam and a New International Economic Order: The Social Dimension, Geneva, 7-10 January.

Naqvi, S. N. H. (1981). Ethics and Economics: An Islamic Synthesis, Islamabad: The Islamic Foundation.

Naqvi, S. N. H. (1983). Individual Freedom, Social Welfare and Islamic Economic Order, Islamabad: Pakistan Institute of Development Economics.

Naqvi, S. N. H. (1994). Islam, Economics and Society, London and New York: Kegan Paul International.

Safi, L.. (1996). The Foundation of Knowledge, A Comparative Study in Islamic and Western Method of Inquiry, Malaysia: IIUM and IIIT Malaysia Publication.

Siddiqi, M. N. (1978). Some Aspects of the Islamic Economy, $2^{\text {nd }}$ edition, Lahore: Islamic Publication, Ltd.

Siddiqi, M. N. (1981). Muslim Economic Thinking: A Survey of Contemporary Literature, United Kingdom: Islamic Foundation.

Siddiqi, S. A. (2001). A Suggested methodology for the political economy of Islam, JKAU: Islamic Economics, 13, 97-118.

Syeik Idris, J. (1987). The Islamization of sciences: its philosophy and methodology, The American Journal of Social Sciences, 4(2), 201-224.

Zarqa, M. A. (2003). Islamization of economics: the concept and methodology, JKAU: Islamic Economics, 16(1), 3-41. 